\title{
Extracellular Pectinase from a Novel Bacterium Chryseobacterium indologenes Strain SD and Its Application in Fruit Juice Clarification
}

\author{
Karabi Roy $\mathbb{D}^{D}$, Sujan Dey (D), Md. Kamal Uddin (iD, Rasel Barua, and Md. Towhid Hossain \\ Department of Microbiology, University of Chittagong, Chittagong 4331, Bangladesh \\ Correspondence should be addressed to Sujan Dey; sujan.mbio@cu.ac.bd
}

Received 21 September 2017; Revised 24 January 2018; Accepted 11 February 2018; Published 21 March 2018

Academic Editor: Denise Freire

Copyright (c) 2018 Karabi Roy et al. This is an open access article distributed under the Creative Commons Attribution License, which permits unrestricted use, distribution, and reproduction in any medium, provided the original work is properly cited.

\begin{abstract}
Pectinase is one of the important enzymes of industrial sectors. Presently, most of the pectinases are of plant origin but there are only a few reports on bacterial pectinases. The aim of the present study was to isolate a novel and potential pectinase producing bacterium as well as optimization of its various parameters for maximum enzyme production. A total of forty bacterial isolates were isolated from vegetable dump waste soil using standard plate count methods. Primary screening was done by hydrolysis of pectin. Pectinase activity was determined by measuring the increase in reducing sugar formed by the enzymatic hydrolysis of pectin. Among the bacterial isolates, the isolate K6 exhibited higher pectinase activity in broth medium and was selected for further studies. The selected bacterial isolate K6 was identified as Chryseobacterium indologenes strain SD. The isolate was found to produce maximum pectinase at $37^{\circ} \mathrm{C}$ with $\mathrm{pH} 7.5$ upon incubation for 72 hours, while cultured in production medium containing citrus pectin and yeast extract as $\mathrm{C}$ and $\mathrm{N}$ sources, respectively. During enzyme-substrate reaction phase, the enzyme exhibited its best activity at $\mathrm{pH}$ of 8.0 and temperature of $40^{\circ} \mathrm{C}$ using citrus pectin as substrate. The pectinase of the isolate showed potentiality on different types of fruit juice clarification.
\end{abstract}

\section{Introduction}

Enzymes are biological molecules that accelerate biochemical reactions. Pectinases are the group of enzymes that prompt the degradation of pectic substances through depolymerization and deesterification reaction [1]. Pectinase is also a wellknown term for commercial enzyme preparation during fruit juice clarification. This enzyme disunites polygalacturonic acid into mono-galacturonic acid by opening glycosidic linkages [2].

In the world market, it has been reported that pectinase accounts for $10 \%$ of global industrial enzymes produced [3]. Pectinolytic enzymes are produced by many organisms like bacteria, fungi, yeasts, insects, nematodes, protozoan, and plants. Among the various pectinases, bacterial pectinases take more advantages over other pectinases. With the passage of time, many reports have been published on the optimization of different microbiological parameters and fermentation strategies for the production of pectinases [4].

Pectinases have immense applications in fruit juice industries to improve fruit juice clarity and yield [5]. Pectinases also have other various industrial applicationïż£s like scouring of cotton, degumming of plant fibers, waste water treatment, and vegetable oil extraction so used in various industries as pulp industry, textile industry, food industry, and so on. The application of pectinase enzyme to alter the texture or flavor of fruit juice, to increase extraction and clarification, and to reduce viscosity has also been described [6].

Keeping all the above advantages of pectinase enzymes in consideration, the aim of the present study was designed to isolate potential pectinolytic microorganisms, optimize their cultural conditions for maximum pectinase production, and investigate different factors involved in maximum pectinase activity and also to evaluate its potentiality in different fruit juice clarification. 


\section{Material and Methods}

2.1. Sampling and Screening. Pectinase producing bacteria were isolated from vegetable dump waste soil. From the collected samples, 40 bacterial isolates were isolated and purified by following standard plate count techniques described by Dubey and Maheshwari [7]. Among 40 isolates, eight isolates were found to produce pectinase while grown on yeast extract pectin agar (YEP) medium during primary screening. Screening of pectinase producing bacteria was carried out in YEP agar medium containing yeast extract $1 \%$, pectin $1 \%$, agar $1.5 \%$, and $\mathrm{NaCl} 0.5 \%(\mathrm{pH} 7.0)$ at $37^{\circ} \mathrm{C}$ for 48 hours of incubation. After incubation, the colonies showing clear zones upon flooding with iodine-potassium iodide solution ( $1.0 \mathrm{~g}$ iodine, $5.0 \mathrm{~g}$ potassium iodide, and $330 \mathrm{~mL} \mathrm{H}_{2} \mathrm{O}$ ) were selected as pectinase producers [8] and the isolate $\mathrm{K} 6$ with the maximum zone of diameter was preceded for further studies.

2.2. Identification of Selected Bacterial Strain by Phenotypic and Biochemical Characteristics. The selected isolate was identified by morphological, cultural, and biochemical characteristics. Colony characteristics of the isolate were determined on yeast extract-pectin agar slant and cellular morphology by Gram staining method. For biochemical characteristics, several tests like citrate test, TSI (triple sugar iron) test, indole test, MR-VP, motility, catalase, oxidase, starch hydrolysis, and fermentation tests for various sugars such as glucose, sucrose, lactose, maltose, starch, and mannitol tests were done.

2.3. Molecular Identification of the Bacterial Isolate Using $16 S$ rRNA Sequencing. Simultaneously, this potential isolate was further identified using the molecular tool of $16 \mathrm{~S}$ rRNA sequencing. In this method, Promega ${ }^{\circledR}$ Wizard $^{\circledR}$ DNA purification kit was used for the extraction of genomic DNA of the selected isolate. 16S rRNA gene region was amplified with the universal primers. The reaction mixtures were $5 \mu \mathrm{l}$ of template, primers: $1 \mu \mathrm{l}$ of forward primer: $27 \mathrm{~F}\left(5^{\prime}\right.$ AGAGTTTGATCCTGGCTCAG $3^{\prime}$ ), $1 \mu$ l of reverse primer: 1492R (5' TACCTTGTTACGACTT $3^{\prime}$ ), $6 \mu$ l of assay buffer, $2 \mu \mathrm{l}$ of Taq DNA polymerase, and $5 \mu \mathrm{l}$ of dNTP mix. PCR products were purified by using the PCR KlenzolTM and it was sequenced with a next-generation DNA sequencing. The sequencing results were then processed using BioEdit software. The nucleotide sequence analysis was done using the Basic Local Alignment Search Tool (BLAST) program on National Center for Biotechnology Information site (https://www.ncbi.nlm.nih.gov). The obtained sequence data were submitted to NCBI GenBank with accession number KY684254. Phylogenetic analysis was conducted in Molecular Evolutionary Genetics Analysis software version 7.0 (MEGA7) [9].

2.4. Preparation of Inoculum. For the production of pectinase enzyme, the inoculum was prepared by inoculating $10 \mathrm{~mL}$ of sterilized YEP liquid medium in a test tube with one loop full of pure culture and incubated at $125 \mathrm{rpm}$ at $37^{\circ} \mathrm{C}$. The fresh overnight grown pure culture was used as an inoculum for enhanced enzyme production.
2.5. Production of Pectinase Enzyme. The inoculum (5\% $\mathrm{v} / \mathrm{v})$ was transferred aseptically to $50 \mathrm{~mL}$ of production medium (yeast extract pectate broth showing the following composition: yeast extract $1 \%$, pectin $1 \%, \mathrm{NaCl} 0.5 \%$, and distilled water $100 \mathrm{ml}$ ) in $250 \mathrm{~mL}$ conical flask and incubated at $37^{\circ} \mathrm{C}$ for 72 hours with $125 \mathrm{rpm}$ in a shaking incubator [10]. After incubation, the production medium was centrifuged at $7000 \mathrm{rpm}$ for $15 \mathrm{~min}$ at $4^{\circ} \mathrm{C}$ to obtain cell-free supernatant. The supernatant was used as the crude enzyme for further studies.

2.6. Pectinase Assay. The pectinase activity was assayed by estimating the amount of reducing sugars released under assay conditions by the enzymatic degradation of citrus pectin. The reaction mixture containing $1.8 \mathrm{ml}$ substrate (citrus pectin) solution and $0.2 \mathrm{ml}$ suitably diluted enzyme solution was incubated at $40^{\circ} \mathrm{C}$ in water bath for 1 hour. The amount of reducing sugar liberated was quantified by Nelson's modification of Somogyi method $[11,12]$. One unit of enzyme activity (U) was defined as the amount of enzyme required to release $1 \mu \mathrm{mol}$ of reducing sugar per $\mathrm{ml}$ per minute under standard assay conditions $\left(1 \mathrm{U}=1 \mu \mathrm{molmin}^{-1} \mathrm{~mL}^{-1}\right)$ [13]. The color intensity was measured at $500 \mathrm{~nm}$ in a colorimeter [SpectroT60 (UV-VIS RS)] and compared with a standard curve prepared with "D-glucose" (25-200 micrograms). Control was maintained with uninoculated media and boiled enzyme. Relative activity of the enzyme was calculated as the percentage by using the following formula:

\section{Relative Activity}

= Activity of the sample

$$
\times \frac{100}{\text { Maximum activity of the sample }}
$$

2.7. Total Protein Estimation. The total protein content was determined by Lowry method [14] measuring the absorbance at $600 \mathrm{~nm}$ and compared with a standard curve prepared by bovine serum albumin (BSA).

\subsection{Optimization of Different Factors Involved in Maximum Pectinase Production}

2.8.1. Effect of Temperature, $p H$, and Incubation Time. The bacterial isolate was subjected to different culture conditions to derive the optimum conditions for maximum pectinase production. Pectinase production was estimated at different temperatures $\left(27,30,37,40\right.$, and $\left.45^{\circ} \mathrm{C}\right)$, a wide range of $\mathrm{pH}$ $(5.0,5.5,6.0,6.5,7.0,7.5,8.0,8.5$, and 9.0), and different incubation periods $(24,48,72,96$, and 120 hours), and then the enzyme activity was measured.

2.8.2. Effect of Carbon and Nitrogen Sources. To study the effect of carbon and nitrogen sources on pectinase production from the selected isolate, various carbon sources (citrus pectin, glucose, sucrose, and starch) and nitrogen sources (peptone, yeast extract, ammonium chloride, and potassium nitrate) were supplemented into production medium at a 
concentration of $0.5 \% \mathrm{w} / \mathrm{v}$ and then the pectinase activity was assayed.

2.9. Optimization of Reaction Parameters for the Maximum Pectinase Activity. Various reaction parameters were studied to determine the optimum conditions of the crude pectinase activity at different temperature, $\mathrm{pH}$, reaction time, and substrate concentration.

2.9.1. Effect of Temperature and $p H$. The optimum temperature and $\mathrm{pH}$ of the pectinase enzyme were determined by incubating the reaction mixture having $\mathrm{pH} 7.5$ at various temperatures $\left(30,37,40\right.$, and $\left.45^{\circ} \mathrm{C}\right)$, and then a range of $\mathrm{pH}$ $(6.0,6.5,7.0,7.5,8.0,8.5$, and 9.0$)$ at $40^{\circ} \mathrm{C}$ for 1 hour using different buffers, respectively. For this purpose, substrate (1\% $\mathrm{w} / \mathrm{v}$ citrus pectin) was prepared at different $\mathrm{pH}$ values $(\mathrm{pH}$ 6.0-9.0) using $0.2 \mathrm{M}$ citrate-phosphate buffer ( $\mathrm{pH}$ 6.0-7.5) and $0.2 \mathrm{M}$ Tris- $\mathrm{HCl}$ buffer ( $\mathrm{pH} 8.0-9.0)$. Then the pectinase activity was assayed by using the standard assay method.

2.9.2. Effect of Reaction Time. For determination of optimum reaction time, the enzyme stability was studied by incubating the reaction mixture for various time intervals at $10 \mathrm{~min}$, $20 \mathrm{~min}, 30 \mathrm{~min}, 40 \mathrm{~min}, 50 \mathrm{~min}$, and $60 \mathrm{~min}$ under optimized temperature and $\mathrm{pH}$ and then performing the assay for pectinase activity.

2.9.3. Effect of Substrate Concentration. To examine the effect of substrate concentration during enzyme-substrate reaction, varying concentrations of citrus pectin $(0.5,1.0,1.5,2.0$, 2.5 , and $3.0 \%$ ) were prepared and then enzyme activity was measured.

2.10. Crude Pectinase Enzyme in Fruit Juice Clarification. To observe the effect of crude pectinase on different fruit juice clarification, tubes were labeled as treatment and control. $10 \mathrm{ml}$ of crude pectinase was taken into the test tube (treatment) and $10 \mathrm{ml}$ of distilled water was taken into the control test tube. Then twenty $\mathrm{ml}$ of apple/grape juice was added to both tubes. The contents of the tubes were agitated to mix the enzymes throughout the juice. The tubes were kept into the water bath at $40^{\circ} \mathrm{C}$. The tubes were observed at 5 -minute intervals over one-hour period. After incubation, the solution was filtered [15].

\section{Results and Discussion}

There are only a few reports on bacterial pectinases till now [16]. In this study, we aimed to find out novel and potential pectinolytic bacteria, to optimize the cultural conditions for enhancing enzyme production and partial characterization of the enzyme. For this purpose, we collected vegetable dump waste soil as the source of potential organisms. Eight isolates were primarily selected from 40 bacterial isolates on the basis of their pectinolytic activity, as shown in Figure 1, during screening and finally, the isolate K6 was selected for further studies.

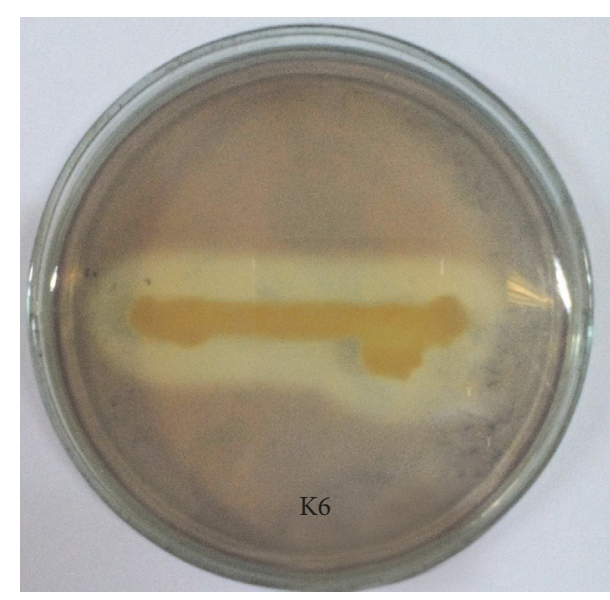

FIGURE 1: Zone of pectin hydrolysis on YEP agar medium of isolate K6 after 48-hour incubation.

3.1. Identification of Selected Bacterial Isolate. To identify the selected isolate $\mathrm{K} 6$, both traditional microbiological methods and modern molecular technologies were considered. On the basis of observed morphological, cultural, and biochemical characteristics, the selected isolate was compared with the standard description in Bergey's Manual of Determinative Bacteriology [17] and the isolate K6 was provisionally identified as Chryseobacterium indologenes.

In NCBI database, BLAST showed significant alignments of Chryseobacterium indologenes with 95\% similarities. Further, the obtained sequence was compared with other related sequences to find the closest homolog at NCBI using BLAST. The construction of a phylogenetic tree (Figure 2) was made on the basis of $16 \mathrm{~S}$ rRNA gene sequences of isolate Chryseobacterium indologenes strain SD and other strains of Chryseobacterium species obtained from GenBank database. The related 16 nucleotide sequences were used to construct the phylogenetic tree using the neighbor-joining method [18]. The bootstrap consensus tree inferred from 1000 replicates [19] is taken to represent the evolutionary history of the taxa analyzed [19]. Branches corresponding to partitions reproduced in less than $50 \%$ bootstrap replicates are collapsed. The percentage of replicate trees in which the associated taxa clustered together in the bootstrap test (1000 replicates) is shown next to the branches [19]. The evolutionary distances were computed using the Maximum Composite Likelihood method [20] and are in the units of the number of base substitutions per site. The analysis involved 16 nucleotide sequences. All positions containing gaps and missing data were eliminated. There were a total of 1323 positions in the final dataset. Evolutionary analyses were conducted in MEGA7 [9]. Finally, the result attained from the 16S rRNA analyses inferred that the Chryseobacterium indologenes strain SD was very close to other Chryseobacterium indologenes strains.

3.2. Optimization Studies of the Isolate for Pectinase Production. To optimize the culture conditions of this potential organism in the production medium different temperature, 


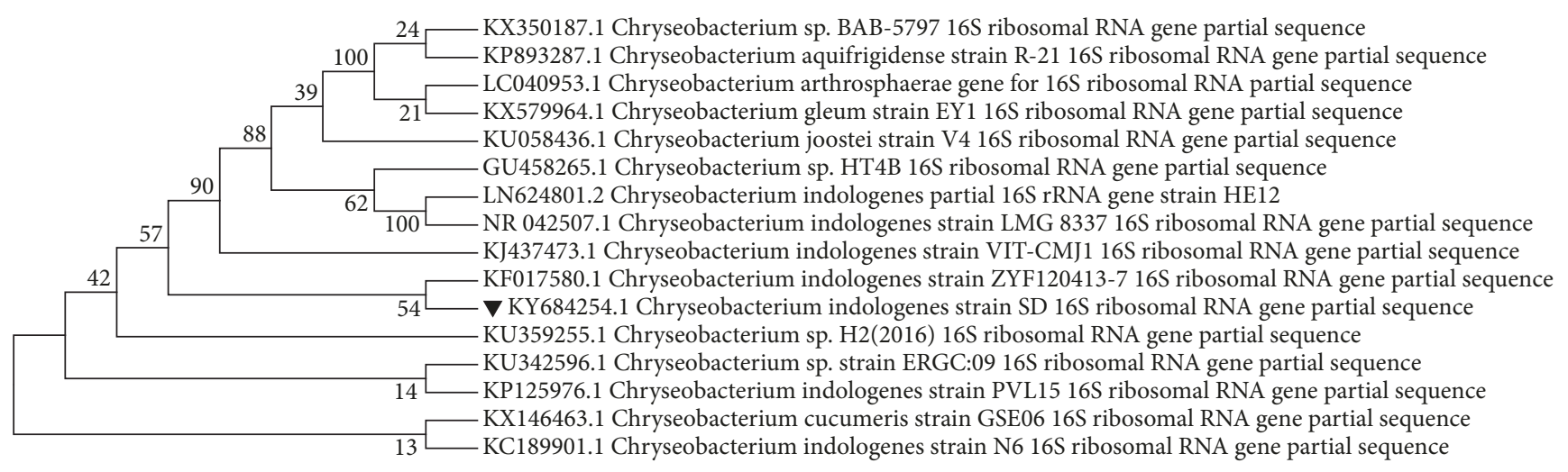

FIGURE 2: Phylogenetic tree constructed on the basis of 16S rRNA gene sequences of Chryseobacterium indologenes strain SD with other Chryseobacterium sp. obtained from GenBank database. Their names and respective accession numbers are shown on the tree.

TABLE 1: Effect of temperature on pectinase production from Chryseobacterium indologenes strain SD.

\begin{tabular}{lcc}
\hline $\begin{array}{l}\text { Incubation } \\
\text { temperature }\left({ }^{\circ} \mathrm{C}\right)\end{array}$ & $\begin{array}{c}\text { Enzyme activity } \\
\left(\mu \mathrm{molmin}^{-1} \mathrm{~mL}^{-1}\right)\end{array}$ & $\begin{array}{c}\text { Relative activity } \\
(\%)\end{array}$ \\
\hline 27 & $0.36 \pm 0.050$ & 52.94 \\
30 & $0.45 \pm 0.020$ & 66.18 \\
37 & $0.68 \pm 0.020$ & 100.0 \\
40 & $0.24 \pm 0.021$ & 35.3 \\
45 & $0.18 \pm 0.026$ & 26.47 \\
\hline
\end{tabular}

Values are mean \pm SD of 3 replicates.

$\mathrm{pH}$, incubation period, and various $\mathrm{C}$ and $\mathrm{N}$ sources were considered. Enzyme production went up with the increase of temperature up to $37^{\circ} \mathrm{C}$ and then declined (Table 1). The maximum production which occurred at this temperature was $0.679 \mathrm{U} / \mathrm{ml}(100 \%$ of relative activity). This dramatically reduced to nearly $27 \%$ at $45^{\circ} \mathrm{C}$ temperature. In the previous study of Aaisha and Barate (2016) [21], the highest pectinase production was observed from some Bacillus species at $37^{\circ} \mathrm{C}$ which is similar to our current study. The same findings were also reported by the other workers [22] in case of mutagenic strain of Leuconostoc mesenteroides.

The same trend was also observed when this organism was allowed to grow in the production medium at varying $\mathrm{pH}$ (Table 2). Maximum production $(0.564 \mathrm{U} / \mathrm{ml})$ was recorded at $\mathrm{pH}$ 7.5. This finding is in accordance with other workers who reported that most of the Bacillus sp. produce high amount of pectinase between $\mathrm{pH} 7.5$ and 8 [21, 23]. At highly acidic and alkaline $\mathrm{pH}$, enzyme production decreased by almost $34 \%$ and $64 \%$, respectively. From this result, it can be inferred that, at very low and very high $\mathrm{pH}$ condition, growth of the organism slows down.

An attempt was made to determine the most favorable time period for enzyme production by the selected isolate and the highest enzyme production $(0.594 \mathrm{U} / \mathrm{ml})$ was recorded at 72 hours of incubation (Table 3 ). The enzyme production gradually decreased to $0.35 \mu \mathrm{molmin}^{-1} \mathrm{~mL}^{-1}$ at 120 hours of incubation which is almost $40 \%$ less than that of maximum. This might be due to the accumulation of
TABLE 2: Effect of $\mathrm{pH}$ on pectinase production from Chryseobacterium indologenes strain SD.

\begin{tabular}{lcc}
\hline $\mathrm{pH}$ & $\begin{array}{c}\text { Enzyme activity } \\
\left(\mu \mathrm{molmin}^{-1} \mathrm{~mL}^{-1}\right)\end{array}$ & Relative activity $(\%)$ \\
\hline 5.0 & $0.37 \pm 0.020$ & 66.07 \\
5.5 & $0.42 \pm 0.026$ & 75.00 \\
6.0 & $0.45 \pm 0.026$ & 80.36 \\
6.5 & $0.47 \pm 0.020$ & 83.93 \\
7.0 & $0.48 \pm 0.020$ & 85.71 \\
7.5 & $0.56 \pm 0.021$ & 100.0 \\
8.0 & $0.40 \pm 0.025$ & 71.43 \\
8.5 & $0.33 \pm 0.020$ & 58.93 \\
9.0 & $0.21 \pm 0.038$ & 37.5 \\
\hline
\end{tabular}

Values are mean $\pm \mathrm{SD}$ of 3 replicates.

TABLE 3: Effect of incubation period on pectinase production from Chryseobacterium indologenes strain SD.

\begin{tabular}{lcc}
\hline $\begin{array}{l}\text { Incubation period } \\
\text { (hour) }\end{array}$ & $\begin{array}{c}\text { Enzyme activity } \\
\left(\mu \mathrm{molmin}^{-1} \mathrm{~mL}^{-1}\right)\end{array}$ & $\begin{array}{c}\text { Relative activity } \\
(\%)\end{array}$ \\
\hline 24 & $0.45 \pm 0.020$ & 76.27 \\
48 & $0.50 \pm 0.040$ & 84.75 \\
72 & $0.59 \pm 0.030$ & 100.0 \\
96 & $0.52 \pm 0.021$ & 88.14 \\
120 & $0.35 \pm 0.032$ & 59.32 \\
\hline
\end{tabular}

Values are mean \pm SD of 3 replicates.

waste products at prolonged incubation time with limited nutrient sources which consequently suppressed the growth of microorganism. According to Nawawi et al. (2017) [24], maximum pectinase production was determined from the Bacillus subtilis ADI1 after 72 hours of incubation which well agreed with our findings.

In this study, we also supplemented different types of carbon and nitrogen sources to find out the suitable production medium for pectinase production by Chryseobacterium indologenes strain $\mathrm{SD}$. Among the four $\mathrm{C}$ sources, the organism lost almost $50 \%$ of production in case of sucrose 
TABLE 4: Effect of carbon sources on pectinase production from Chryseobacterium indologenes strain SD.

\begin{tabular}{lcc}
\hline Carbon source & $\begin{array}{c}\text { Enzyme activity } \\
\left(\mu \mathrm{molmin}^{-1} \mathrm{~mL}^{-1}\right)\end{array}$ & Relative activity (\%) \\
\hline Citrus pectin & $0.67 \pm 0.020$ & 100.0 \\
Glucose & $0.64 \pm 0.021$ & 95.52 \\
Sucrose & $0.38 \pm 0.030$ & 56.72 \\
Starch & $0.50 \pm 0.020$ & 74.63 \\
\hline
\end{tabular}

Values are mean \pm SD of 3 replicates.

TABLE 5: Effect of nitrogen sources on pectinase production from Chryseobacterium indologenes strain SD.

\begin{tabular}{lcc}
\hline Nitrogen source & $\begin{array}{c}\text { Enzyme activity } \\
\left(\mu \mathrm{molmin}^{-1} \mathrm{~mL}^{-1}\right)\end{array}$ & $\begin{array}{c}\text { Relative activity } \\
(\%)\end{array}$ \\
\hline Yeast extract & $0.61 \pm 0.020$ & 100.0 \\
Peptone & $0.55 \pm 0.020$ & 90.16 \\
Potassium nitrate & $0.46 \pm 0.036$ & 75.41 \\
Ammonium chloride & $0.42 \pm 0.021$ & 68.85 \\
\hline
\end{tabular}

Values are mean \pm SD of 3 replicates.

utilization. It showed the highest production of $0.671 \mathrm{U} / \mathrm{ml}$, while citrus pectin was used in the medium as $\mathrm{C}$ source and almost the same result was found in case of glucose supplement (Table 4) suggesting that the organism exploited citrus pectin more efficiently as compared to other $\mathrm{C}$ sources. Prakash et al. (2014) [25] observed the highest production of pectinase with lactose and glucose and Jayani et al. (2010) [26] reported citrus pectin as the best carbon source for pectinase production by Bacillus sphaericus. However, some researchers reported the maximum pectinase production from Bacillus subtilis ADI1 using rice brain as carbon source [24].

Likewise, the best enzyme production of this isolate was recorded when yeast extract was used as $\mathrm{N}$ source in the medium and the organism also produced nearly the same amount of enzyme when peptone was supplemented which indicates that this organism preferred yeast extract as compared to other $\mathrm{N}$ sources (Table 5). On top of that, our study revealed that organic nitrogen was used as better $\mathrm{N}$ sources by this organism than inorganic sources for enzyme production. These results are completely aligned with the findings of the other workers $[25,26]$.

Finally, by applying all the optimized parameters, the isolate was allowed to produce the enzyme in the production medium and we observed little increase in pectinase production $(0.689 \mathrm{U} / \mathrm{ml})$.

3.3. Total Protein Estimation for Crude Enzyme. Protein concentration of the crude enzyme was determined by FolinLowry method [14]. The total protein content was $1320 \mu \mathrm{g} / \mathrm{ml}$ in the cell-free supernatant of Chryseobacterium indologenes strain SD.

3.4. Optimization Studies of Pectinase Activity. By growing the organism in the production medium under optimized

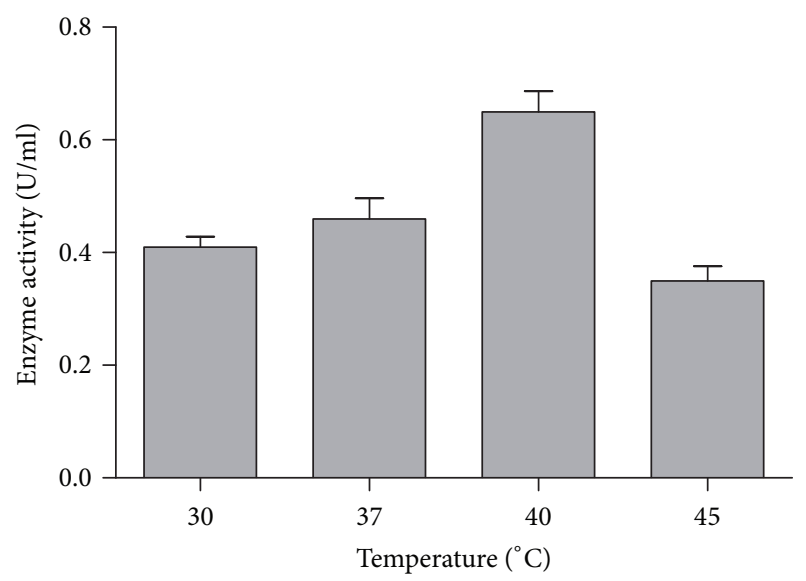

FIGURE 3: Effect of temperature on pectinase activity.

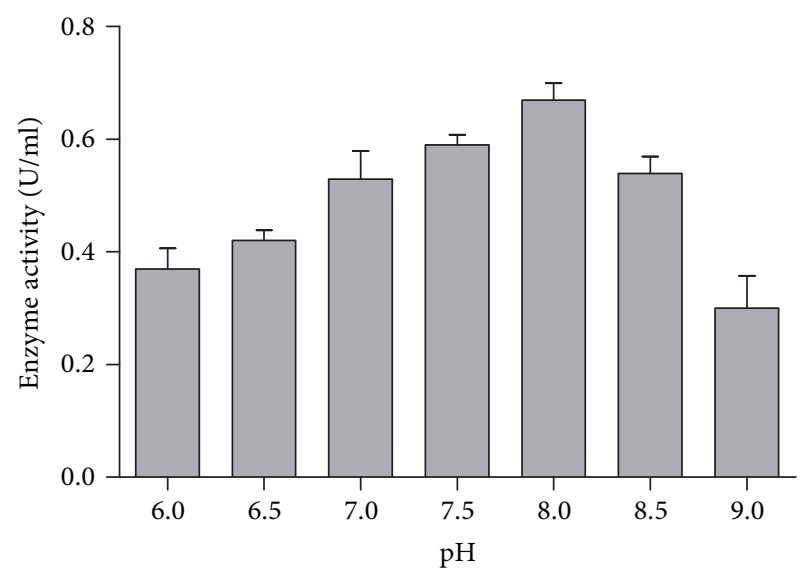

FIGURE 4: Effect of $\mathrm{pH}$ on pectinase activity.

conditions, the crude was collected by centrifugation to determine optimum conditions of the pectinase activity. Then the collected crude enzyme was allowed to react with different substrate concentrations (citrus pectin) at a wide range of temperatures, $\mathrm{pH}$, and reaction time.

In this research work, the crude enzyme obtained from Chryseobacterium indologenes strain SD showed maximum activity at $40^{\circ} \mathrm{C}$ (Figure 3), whereas the organism showed the highest production at $37^{\circ} \mathrm{C}$. This result is approximately similar to the result of other studies [27]. However, some studies reported [28] that pectinases from various Bacillus species were most active at $50^{\circ} \mathrm{C}$ and $60^{\circ} \mathrm{C}$. From our study, it can be inferred that pectinase enzyme produced by the isolate is a moderately thermophilic enzyme.

Enzyme activity also depends on the $\mathrm{pH}$ of the reaction mixture. In our study, crude enzyme showed the highest activity at slightly alkaline $\mathrm{pH} 8$ (Figure 4 ) and the organism also showed its maximum production at $\mathrm{pH}$ 7.5. Therefore, this enzyme can be used for vegetable purees and other preparations which need neutral to slightly alkaline $\mathrm{pH}$ [29]. This finding is in accordance with the reports of previous studies [28]. So, the result of our study indicates that this crude enzyme might be alkaline in nature. 


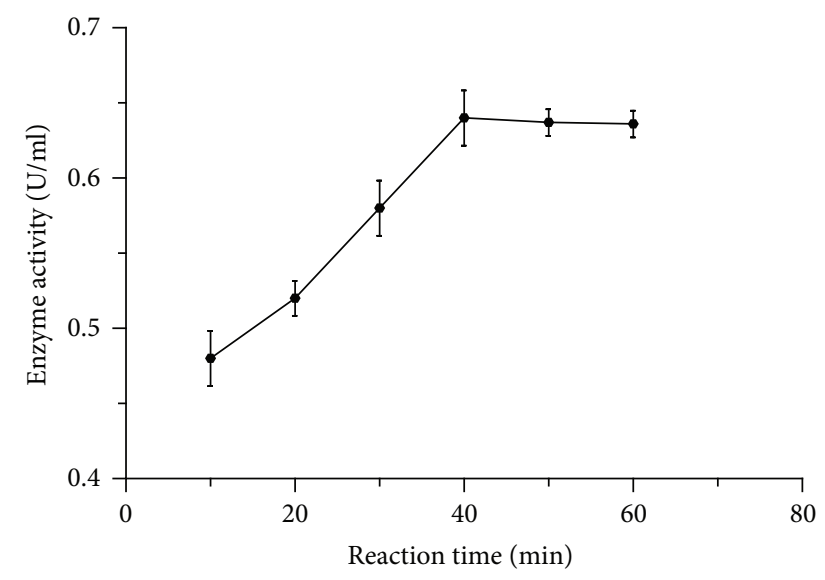

FIGURE 5: Effect of reaction time on pectinase activity.

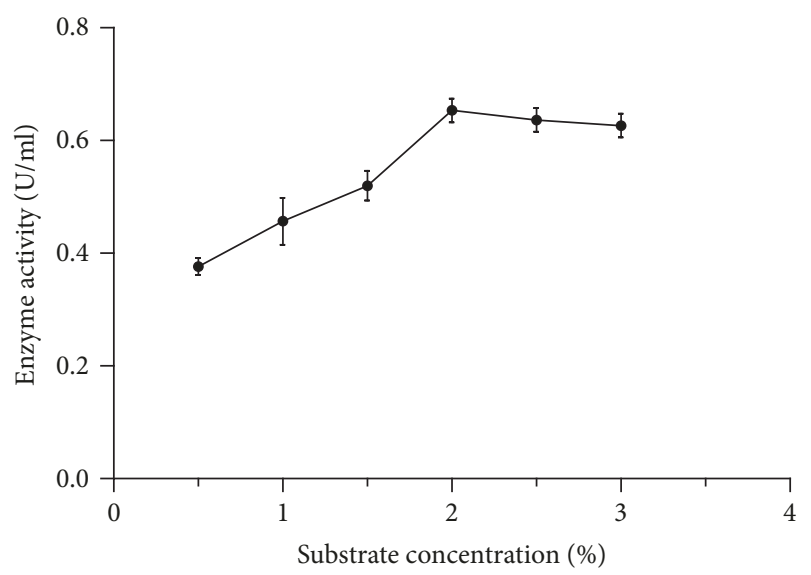

FIGURE 6: Effect of substrate (citrus pectin) concentration on pectinase activity.

As incubation time affects the activity of the enzyme, the crude enzyme was allowed to react with $1 \%$ of citrus pectin as substrate at optimized $\mathrm{pH}$ and temperature for different time intervals to determine its optimum reaction time. In our study, enzyme activity increased with the increase of incubation time up to $40 \mathrm{~min}$ and then remained stable in the subsequent incubation period (Figure 5). This result is in a good agreement with other studies [30].

The enzyme assay using different concentrations of substrate (citrus pectin) was observed and found that the enzyme activity augmented up to $2 \%$ of pectin and then it showed downward trend before being leveled off at $98 \%$ of relative activity in the subsequent increase of substrate concentration (Figure 6). This might be due to complete saturation of enzyme by the substrate.

3.5. Application of Crude Pectinase Enzyme in Fruit Juice Clarification. The effect of crude pectinase of the bacterial isolate Chryseobacterium indologenes strain SD was studied for apple/grape juice clarification. The crude enzyme of the selected isolate showed good activities by clarifying the juices as compared to control (Figure 7).

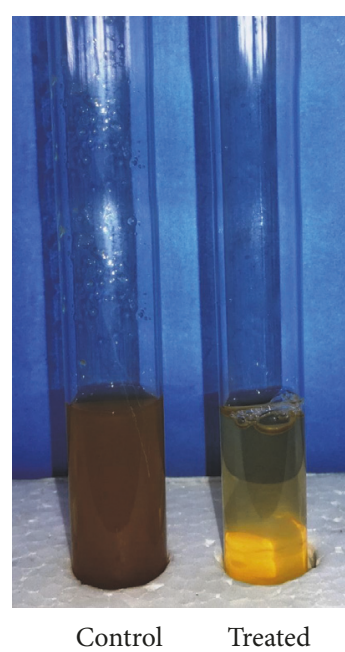

(a)

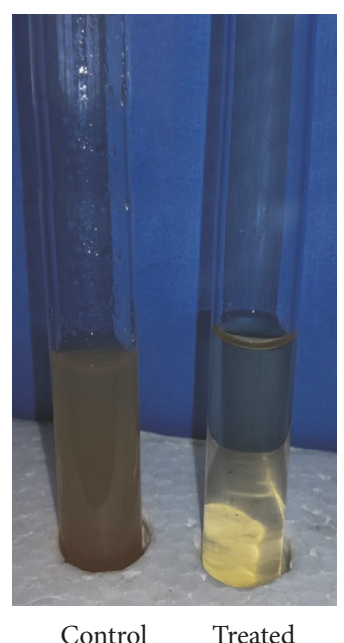

(b)
FIGURE 7: Application of pectinase in apple juice (a) and grape juice (b) clarification.

\section{Conclusion}

Nowadays, the need of industrially important enzymes has increased rapidly. Pectinase enzyme has taken great attraction in the field of juice clarification and other commercial applications. In this study, Chryseobacterium indologenes strain $\mathrm{SD}$ was found as a potential pectinase producer and it is the first report on Chryseobacterium indologenes strain SD. In this investigation, the crude enzyme was found to be slightly alkaline in nature and best active at $40^{\circ} \mathrm{C}$ for 40 minutes of incubation. Further studies can be done for complete characterization and purification of the crude enzyme and purified enzymes can be used in various types of fruit juice clarification.

\section{Conflicts of Interest}

The authors declare no conflicts of interest.

\section{Acknowledgments}

The financial support from the Ministry of Science and Technology and University Grant Commission (UGC), Bangladesh, is thankfully acknowledged.

\section{References}

[1] D. B. Pedrolli, A. C. Monteiro, E. Gomes, and E. C. Carmona, "Pectin and pectinases: production, characterization and industrial application of microbial pectinolytic enzymes," The Open Biotechnology Journal, vol. 3, no. 1, pp. 9-18, 2009.

[2] O. A. Oyewole, S. B. Oyeleke, B. E. N. Dauda, and S. Emiade, "Production of Amylase and Protease Enzymes by Aspergillus niger and Penicillium frequestans Isolated from Abattoir Effluent," Journal of Microbiology, vol. 1, no. 5, pp. 174-180, 2011.

[3] F. Stutzenberger, "Pectinase Production," in Encyclopedia of Microbiology, J. Lederberg, Ed., vol. 3, pp. 327-337, Academy press, New York, NY, USA, 1992. 
[4] S. Kaur, H. P. Kaur, B. Prasad, and T. Bharti, "Production and Optimization of Pectinase by Bacillus sp. Isolated From Vegetable Waste Soil," Indo American Journal of Pharmaceutical Research, vol. 6, no. 1, pp. 4185-4190, 2016.

[5] I. Alkorta, C. Garbisu, J. M. Llama, and J. L. Serra, "A Review," ProcessBiochemistry, vol. 17, pp. 35-41, 1982.

[6] K. Prathyusha and V. Suneetha, "Bacterial pectinases and their potent biotechnological application in fruit processing/Juice production industry: A review," Journal of Phytology, vol. 3, no. 6, pp. 16-19, 2011.

[7] R. C. Dubey and D. K. Maheshwari, "Practical Microbiology," in S. Chand and Co. P Ltd, p. 413, ISBN, New Delhi, 2nd edition.

[8] L. K. Janani, G. Kumar, and K. V. Bhaskara Rao, "Production and Optimization of Pectinase from Bacillus sp. MFW7 using Cassava Waste," Asian Journal of Biochemical and Pharmaceutical Research, vol. 1, no. 2, pp. 329-336, 2011.

[9] S. Kumar, G. Stecher, and K. Tamura, "MEGA7: Molecular Evolutionary Genetics Analysis version 7.0 for bigger datasets," Molecular Biology and Evolution, vol. 33, no. 7, pp. 1870-1874, 2016.

[10] D. R. Kashyap, S. Chandra, A. Kaul, and R. Tewari, "Production, purification, and characterization of pectinase from a Bacillus sp," World Journal of Microbiology \& Biotechnology, vol. 16, pp. 277-282, 2000.

[11] N. Nelson, "A photometric adaptation of the Somogyi method for the determination of glucose," The Journal of Biological Chemistry, vol. 153, pp. 375-380, 1944.

[12] M. Somogyi, "Notes on sugar determination," The Journal of Biological Chemistry, vol. 195, no. 1, pp. 19-23, 1952.

[13] D. Silva, E. S. Martins, R. Silva, and E. Gomes, "Pectinase production by Penicillium viridicatum RFC3 by solid state fermentation using agro-industrial by-products," Brazilian Journal of Microbiology, vol. 33, pp. 318-324, 2002.

[14] O. H. Lowry, N. J. Rosebrough, A. L. Farr, and R. J. Randall, "Protein measurement with Folin phenol reagent," The Journal of Biological Chemistry, vol. 193, pp. 265-275, 1951.

[15] S. A. Mehta, R. Mitali, S. Nilofer, and P. Nimisha, “Optimization of physicological parameters for pectinase production from soil isolates and its applications in fruit juice clarification," Journal of Environmental Research and Development, vol. 7, no. 4, pp. 1539-1546, 2013.

[16] R. S. Jayani, S. Saxena, and R. Gupta, "Microbial pectinolytic enzymes: a review," Process Biochemistry, vol. 40, no. 9, pp. 29312944, 2005.

[17] R. E. Buchannan and N. E. Gibbson, Bergey's manual of determinative Bacteriology, Williams and Wilkins Co, Baltimore, Maryland, USA, 8th edition, 1974.

[18] N. Saitou and M. Nei, "The neighbor-joining method: a new method for reconstructing phylogenetic trees," Molecular Biology and Evolution, vol. 4, no. 4, pp. 406-425, 1987.

[19] J. Felsenstein, "Confidence limits on phylogenies: an approach using the bootstrap," Evolution, vol. 39, pp. 783-791, 1985.

[20] K. Tamura, M. Nei, and S. Kumar, "Prospects for inferring very large phylogenies by using the neighbor-joining method," Proceedings of the National Acadamy of Sciences of the United States of America, vol. 101, no. 30, pp. 11030-11035, 2004.

[21] G. Aaisha and D. Barate, "Isolation and Identification of Pectinolytic Bacteria from Soil Samples of Akola Region, India," International Journal of Current Microbiology and Applied Sciences, vol. 5, no. 1, pp. 514-521, 2016.
[22] A. B. Saanu, "Pectinolytic Activity of Mutagenic Strain of Leuconostoc Mesenteroides Isolated From Orange and Banana Fruit Waste," Journal of Applied Microbiology and Biochemistry, vol. 1, no. 2:7, pp. 1-6, 2017.

[23] O. J. Oumer and D. Abate, "Characterization of Pectinase from Bacillus subtilis Strain Btk 27 and Its Potential Application in Removal of Mucilage from Coffee Beans," Enzyme Research, vol. 2017, Article ID 7686904, 7 pages, 2017.

[24] M. H. Nawawi, R. Mohamad, P. M. Tahir, and W. Z. Saad, "Extracellular Xylanopectinolytic Enzymes by Bacillus subtilis ADI1 from EFB's Compost," International Scholarly Research Notices, vol. 2017, Article ID 7831954, 7 pages, 2017.

[25] S. Prakash, R. Karthik, M. T. Venthan, B. Sridhar, and P. G. Bharath, "Optimization and Production of Pectinase from Bacillus subtilis (mtcc 441) by using Orange Peel as a Substrate," International Journal of Recent Scientific Research, vol. 5, no. 6, pp. 1177-1179, 2014.

[26] R. S. Jayani, S. K. Shukla, and R. Gupta, "Screening of bacterial strains for polygalacturonase activity: its production by bacillus sphaericus (MTCC 7542)," Enzyme Research, vol. 2010, Article ID 306785, 5 pages, 2010.

[27] A. Thakur, R. Pahwa, S. Singh, and R. Gupta, "Production, purification, and characterization of polygalacturonase from mucor circinelloides ITCC 6025," Enzyme Research, vol. 2010, Article ID 170549, 7 pages, 2010.

[28] N. Torimiro and R. E. Okonji, "A comparative study of pectinolytic enzyme production by Bacillus species," African Journal of Biotechnology, vol. 12, no. 46, pp. 6498-6503, 2013.

[29] M. M. C. N. Soares, R. Da Silva, and E. Gomes, "Screening of bacterial strains for pectinolytic activity: Characterization of the polygalacturonase produced by Bacillus sp," Brazilian Journal of Microbiology, vol. 30, no. 4, pp. 299-303, 1999.

[30] I. G. Khan and D. L. Barate, "Effect of various parameters on activity of pectinase enzyme," International Journal of Advanced Research, vol. 4, no. 1, pp. 853-862, 2016. 


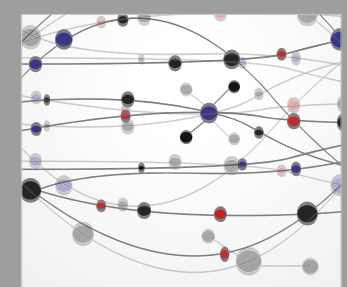

The Scientific World Journal
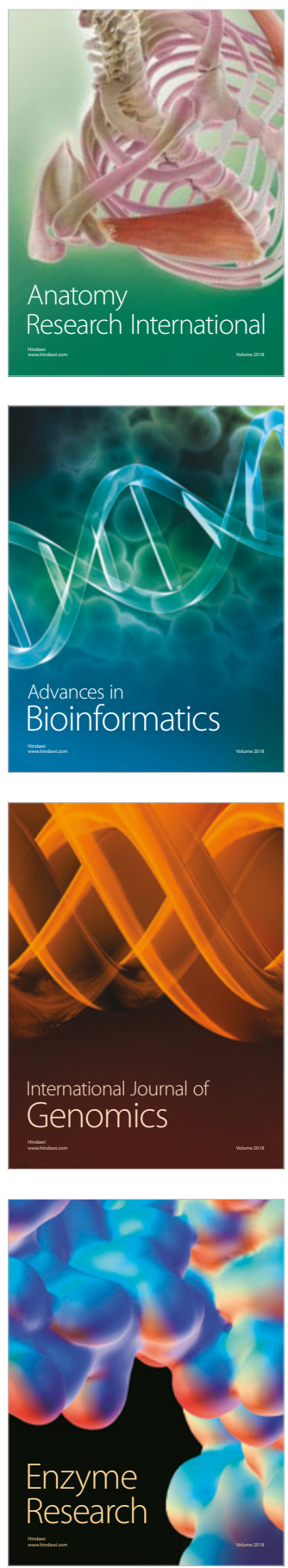
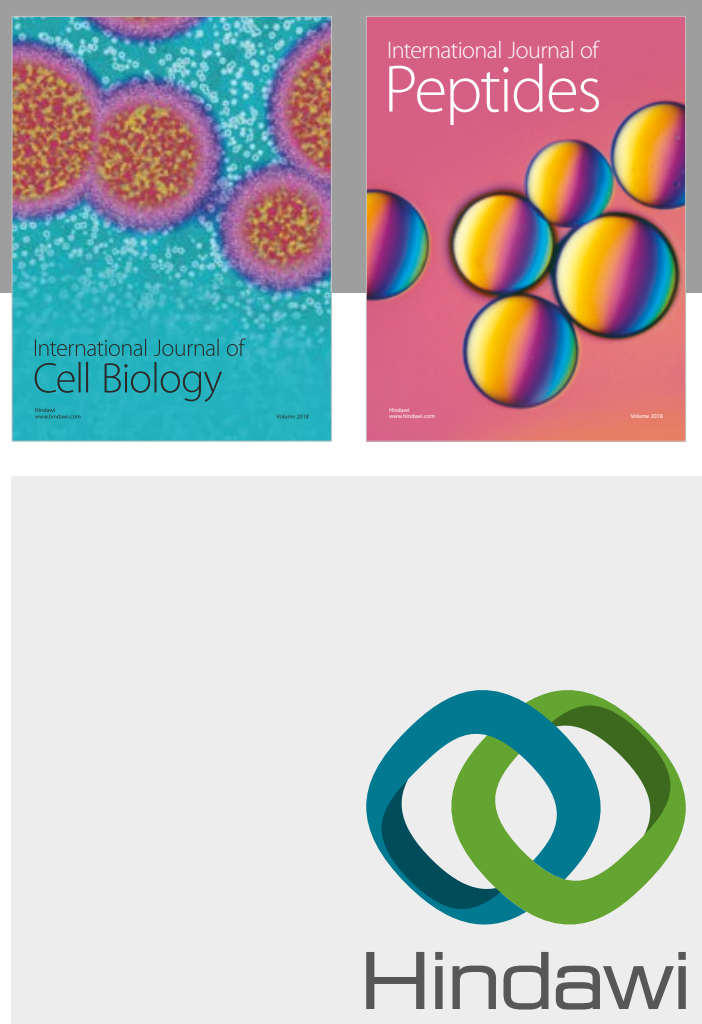

Submit your manuscripts at

www.hindawi.com
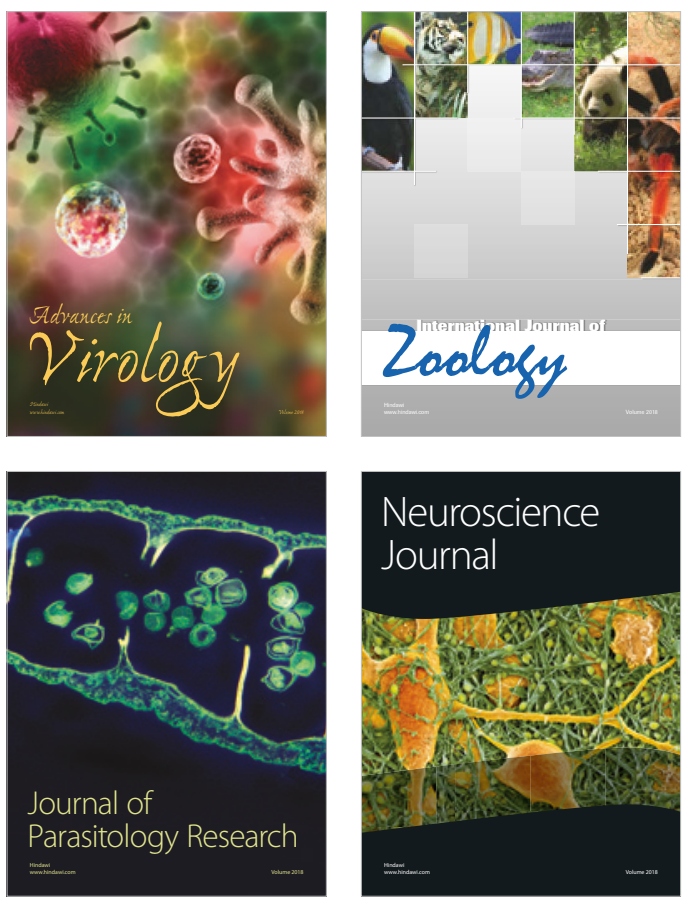
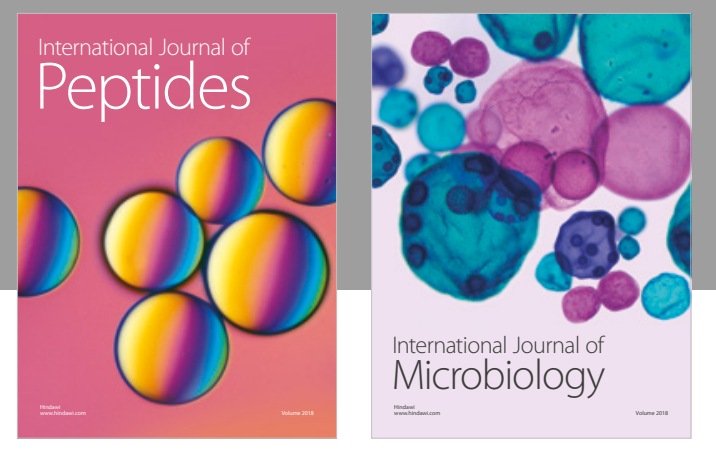

nternational Journal of Microbiology
Journal of
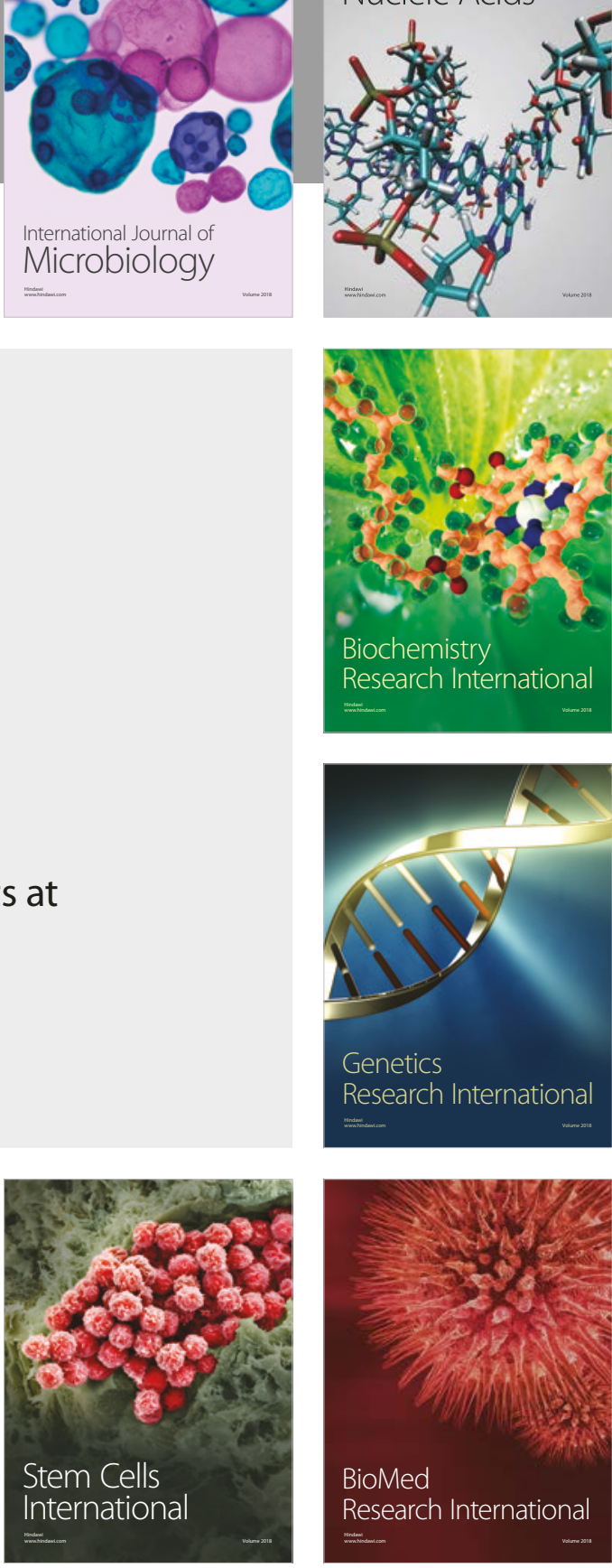
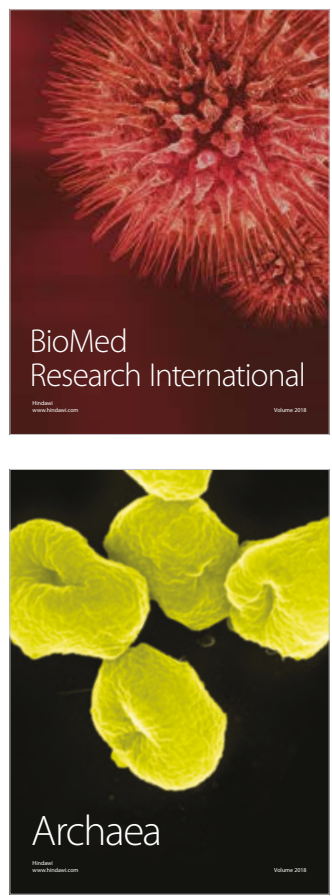